http://jmscr.igmpublication.org/home/ ISSN (e)-2347-176x ISSN (p) 2455-0450

crossref DOI: https://dx.doi.org/10.18535/jmscr/v8i2.144

Journal Of Medical Science And Clinical Research

IGM Publication

An Official Publication of IGM Publication

\title{
Histopathological spectrum of lesions in Nephrectomy specimens in a tertiary care hospital in North India
}

\author{
Authors \\ Anu Gupta ${ }^{1}$, Subhash Bhardwaj ${ }^{2}$ \\ ${ }^{1}$ Lecturer, Department of Pathology, Govt. Medical College, Jammu \\ ${ }^{2}$ Professor \& Head, Department of Pathology, Govt. Medical College, Jammu \\ *Corresponding Author \\ Dr Anu Gupta
}

\begin{abstract}
Introduction: Nephrectomy is a surgical procedure done for various conditions like chronic pyelonephritis, calculi, malignancies, obstruction and injury etc. Histopathological spectrum of various lesions in nephrectomy spectrum were studied to assess the patterns and morphology of lesions and to observe variation if any from the conventional pattern.

Materials \& Method: The study was conducted in the Department of Pathology GMC Jammu over a period of 3 years from Dec 2016 to Jan 2020. 55 nephrectomy specimens were received from the surgical Department of the Hospital.

Results: Out of 55 nephrectomy specimens. 44 (80\%) were benign and 11(20\%) were malignant. Age ranged from 1 year to 72 years with the maximum cases seen in 51-60 years of age. Maximum cases were of Chronic Pyelonephritis 29 (52.72\%), some associated with calculi and others with hydronephrosis. Renal Cell Carcinoma constituted 6 cases (10.90\%) out of 11 total malignant lesions. Wilm's tumour was the commonest malignant tumour seen in children. Most common clinical presentation was flank pain followed by burning micturition and fever.

Conclusion: Benign lesions outnumber the malignant. Chronic Pyelonephritis was the most common histopathological diagnosis and Renal Cell Carcinoma was commonest among the malignant lesions.

Keywords: Nephrectomy, Chronic Pyelonephritis (CPN), Kidney, Histopathology, Renal Cell Carcinoma (RCC).
\end{abstract}

\section{Introduction}

Renal diseases are responsible for a great deal of morbidity and diseases of the kidney are as complex as its structure ${ }^{1}$. Kidneys are vital organs with multiple functions like excretory function, acid base balance and maintenance of salt and water metabolism. Nephrectomy is done for both benign and malignant lesions of the kidney. In the benign category it is indicated for patients with irreversibly damaged kidney resulting from symptomatic chronic infections, obstruction, calculi or severe traumatic injury. In the malignant category, Renal Cell Carcinoma and Wilm's tumour are commonest and nephrectomy is the treatment of choice for Renal Cell Carcinoma ${ }^{2}$. Surgical pathologists should be aware of the importance of both correctly classifying the underlying renal neoplasm and the concomitant non-neoplastic kidney that is likely to be present in these specimens ${ }^{3}$.The study was conducted to evaluate benign and malignant lesions encountered in nephrectomy specimens. 


\section{Material and Methods}

The present study was carried out in Histopathological section of Pathology, Department of Govt. Medical College, Jammu over a period of three years Jan 2016 to Jan 2020. Retrospective analysis of all the 55 nephrectomy specimens received in the department was done. All the relevant data regarding gross findings, clinical details and radiological investigations were reviewed followed by the review of Haemotoxylin \&Eosin stained slides.

\section{Results}

In our study, males constituted 34 cases $(61.81 \%)$ and females 21 cases $(38.18 \%)$ with a M:F of 1.6:1. Maximum number of cases were seen in age group of 51-60 years Table. 1 with the youngest patient of 1 year male presenting with Hemoperitoneum due to traumatic kidney damage and oldest patient of 76 years case of Renal Cell Sarcoma. Benign lesions outnumber the malignant ones Table.2. CPN was seen in maximum number of cases $29(52.72 \%)$ followed by RCC in 6 (10.90\%) Table.3 and 4 (7.27) cases each of Polycystic Kidney disease and Traumatic Kidney damage. There were 2 cases of Wilm's tumor seen in a 3 years old female and a 4 years old Male presenting with the chief complaint of abdominal swelling and hematuria. RCC includes 4 cases of Clear Cell Carcinoma and 2 cases of Papillary Carcinoma Table.4.The most common clinical presentation of patients who underwent nephrectomy was flank pain seen in 40 patients followed by fever and burning micturition in 30 patients Table.5.

Table No.1: Age-wise Distribution of Nephrectomy specimens

\begin{tabular}{|l|c|c|}
\hline Age group & No. of Cases & Percentage (\%) \\
\hline $\mathbf{0 - 1 0}$ & 4 & 7.27 \\
\hline $\mathbf{1 1 - 2 0}$ & 4 & 7.27 \\
\hline $\mathbf{2 1 - 3 0}$ & 7 & 12.72 \\
\hline $\mathbf{3 1 - 4 0}$ & 8 & 14.54 \\
\hline $\mathbf{4 1 - 5 0}$ & 11 & 20 \\
\hline $\mathbf{5 1 - 6 0}$ & 13 & 23.65 \\
\hline $\mathbf{6 1 - 7 0}$ & 6 & 10.90 \\
\hline$>\mathbf{7 0}$ & 2 & 3.65 \\
\hline Total & 55 & 100 \\
\hline
\end{tabular}

Table No.2: Distribution of Benign and Malignant lesions

\begin{tabular}{|l|c|c|}
\hline Lesions & No. of Cases & Percentage (\%) \\
\hline Benign & 44 & 80 \\
\hline Malignant & 11 & 20 \\
\hline Total & 55 & 100 \\
\hline
\end{tabular}

Table No.3: Distribution of Nephrectomy specimens according to Histopathological lesions

\begin{tabular}{|l|c|c|}
\hline Lesions & $\begin{array}{c}\text { No. of } \\
\text { Cases }\end{array}$ & $\begin{array}{c}\text { Percentage } \\
(\boldsymbol{\%})\end{array}$ \\
\hline CPN & 29 & 52.72 \\
\hline $\begin{array}{l}\text { Xanthogranulomatous } \\
\text { Pyelonephritis }\end{array}$ & 3 & 5.45 \\
\hline Pyonephrosis & 2 & 3.63 \\
\hline Polycystic Kidney Disease & 4 & 7.27 \\
\hline Traumatic Kidney & 4 & 7.27 \\
\hline Hydatid Cyst Kidney & 1 & 1.81 \\
\hline Renal Cell Carcinoma & 6 & 10.90 \\
\hline Renal Sarcoma & 2 & 3.63 \\
\hline Wilm's Tumour & 2 & 3.63 \\
\hline Oncocytoma & 1 & 1.81 \\
\hline TCC of Ureter & 1 & 1.81 \\
\hline Total & 55 & 100 \\
\hline
\end{tabular}

Table No.4: Histological types of Renal Cell Carcinoma

\begin{tabular}{|l|c|}
\hline Histological types of tumour & No. of Cases $(\mathbf{n}=\mathbf{6})$ \\
\hline Clear Cell Carcinoma & 4 \\
\hline Papillary Carcinoma & 2 \\
\hline
\end{tabular}

Table No.5: Clinical Presentation in patients undergoing Nephrectomy

\begin{tabular}{|l|c|}
\hline Clinical Features & No. of Patients \\
\hline Hematuria & 09 \\
\hline Flank pain & 40 \\
\hline Fever & 30 \\
\hline Burning Micturition & 35 \\
\hline Lump Abdomen & 10 \\
\hline
\end{tabular}

\section{Discussion}

In the present study, out of 55 nephrectomy specimens studied, $80 \%$ had benign lesions and $20 \%$ had malignant lesions. Thus, benign lesions outnumber the malignant lesions. This is similar to the study done by Aiman $\mathrm{A}^{2}$, Rafique $\mathrm{M}^{4}$. Males constituted 34 cases $(61.81 \%)$ and females constituted 21 cases $(38.18 \%)$ with a M:F ratio of 1.6:1. Similar findings were seen in study done by Lathif $\mathrm{F}^{5}$ and Badmus $\mathrm{TA}^{6}$. However Rafique $\mathrm{M}^{4}$ found slight female preponderance in his study. In our study maximum cases were seen in the age 
group of 51-60 years, similar to the study by Kathirvelu $S^{7}$.In our study, the most common indication for nephrectomy was CPN (52.72\%) followed by RCC (10.90\%) CPN was reported as the most clinical indication in the studies by Popat $\mathrm{VC}$ et $\mathrm{al}^{8}$ and Thaker $\mathrm{BD}^{9}$. In our study there were $3 \quad(5.45 \%)$ cases of Xanthogranulomatous Pyelonephritis. Similar findings were seen by Popat VC et $\mathrm{al}^{8} .1$ case of Xanthogranulomatous Pyelonephritis was misdiagnosed as RCC on radiological findings as it presents as a yellowish mass over the upper pole of kidney. In this study, a total of 11 (20\%) malignant lesions were observed, of these majority i.e 6 cases $(10.90 \%)$ were RCC. This was similar to the findings of Rafique $\mathrm{M}^{4}$ who observed that majority of malignant neoplasms of Kidney were Renal Cell Carcinoma. In our study, microscopically Clear Cell Carcinoma of Kidney was more common than Papillary type similar to study by Shaila ${ }^{10}$ and as per World Health Organistion/International society of Urological Pathology Grading System for clear cell renal cell carcinoma and papillary renal cell carcinoma nuclear grading ${ }^{11}$ majority showed Grade 2 and 3 nuclear features. Renal sarcomas constitute only $1-2 \%$ of malignant renal tumour. In our study 2 cases of renal sarcomas were seen and both in men above 70 years of age group.In this study, the most common clinical feature was flank pain followed by burning micturition and fever. This is comparable to study done by El Malik EM et al ${ }^{12} .2$ cases $(3.63 \%)$ were of Wilms tumor in our study, seen in children of 3 and 5 years of age respectively and both presented with abdominal swelling and hematuria. It is the most common childhood malignant renal tumor. Histologically, it is a triphasic tumour with three elements blastemal stromal and epithelial in varying proportions. No anaplasia was noted in our study. This tumour responds well to chemotherapy.

\section{Conclusion}

Wide range of lesions are encountered when nephrectomy specimens are subjected to
Histopathological

examination.

The

Histopathological diagnosis correlated with clinical diagnosis only 1 case of Xanthogranumomatous Pyelonephritis was misdiagnosed as Renal Cell Carcinoma. Chronic Pyelonephritis was the most common benign lesion, this histopathological spectrum correlated with the available literature studies.

\section{References}

1. Kumar V, K.A, Fausto N. Robbins and Cotran Pathologic Basis of Disease: 2005; 7: 956-962

2. Aiman A, Singh K, Yasir M. Histopathological spectrum of lesions in nephrectomy specimens: A five-year experience in a tertiary care hospital. J Sci Soc 2013;40:148-54.

3. Henriksen KJ, Meehan SM, Chang A. Nonneoplastic Kidney Diseases in Adult Tumor Nephrectomy and Nephroureterectomy Specimens: Common, Harmful, Yet Underappreciated. Archives of Pathology \& Laboratory Medicine 2009; 133: 1012-1025.

4. Rafique M. Nephrectomy: Indications, complications and mortality in 154 consecutive patients. J Pak Med Assoc 2007; 5: 35-8.

5. Lathif F, Mubarak M, Kazi JI. Histopathological characteristics of adult renal tumours: a preliminary report. J Pak Med Assoc 2011; 61: 224-8.

6. Badmus TA, Salako AA, Sansui AA et al. Adult nephrectomy: our experience at llelfe. Niger J Clin Pract 2008; 11(2): 121-6.

7. Kathirvelu S, Rajvaithy A, KV, Kotasthane D. Histopathological spectrum of Nephrectomy specimen in a tertiary care centre: with an emphasis on Chronic Pyelonephritis. Annals of Pathology and Laboratory Medicine. 2017; 4(5): 573-578.

8. Popat VC, Kumar MP, Udani D, Mundra MP, Vora DN, Porecha MM. A Study On Culprit Factors, Ultimately Demanding 
Nephrectomy. The Internet Journal of Urology. 2009; 7(1): 1-8.

9. Thaker BD, Singh K.A Histopathological Review of Nephrectomy Specimens Received in a Tertiary Care Hospital-A Retrospective Study. Journal of Medical Science And clinical Research. 2017; 05(06): 23807-23810.

10. Shaila, Nityananda B.S, Tamil Arasi. Spectrum of lesions in Nephrectomy Specimens in a Tertiary care Hospital. J Evo Med Den Sci. 2015; 4(73): 1271412726.

11. Goldblum J, Lamps L, McKenney J, Myers J. Rosai and Ackerman'sSurgical Pathology. Kidney: Tumour and Tumour like conditions; 2 (11): 1048-1058.

12. El Malik EM, Memon SR, Ibrahim AL, Al Gizawi A, Ghali AM. Nephrectomy in Adults: Asir Hospital Experience. Saudi J Kidney Dis Transpl 1997;8:423-7. 